\title{
Mature and Bi-Sexual Phase Gonad Occurrence in Cultured Red Spotted Grouper, Epinephelus akaara
}

\author{
In Joon Hwang ${ }^{1}$, Byung Hwa Min², and ${ }^{\dagger}$ Hea Ja Baek ${ }^{3}$ \\ 'Inland Fisheries Research Institute, National Institute of Fisheries Science, Gapyeong 12453, Korea \\ ${ }^{2}$ Research and Development Planning Division, National Institute of Fisheries Science, Busan 46083, Korea \\ ${ }^{3}$ Dept. of Marine Biology, Pukyong National University, Busan 48513, Korea
}

Received: June 5, 2020

Revised: August 13, 2020

Accepted: August 26, 2020

${ }^{+}$Corresponding author Hea Ja Baek

Dept. of Marine Biology, Pukyong National University, Busan 48513, Korea

Tel: +82-51-629-5924

Fax: +82-51-629-5931

E-mail:hjbaek@pknu.ac.kr

Copyright $\odot 2020$ The Korean Society of Developmental Biology.

This is an Open Access article distributed under the terms of the Creative Commons Attribution Non-Commercial License (http://creativecommons.org/licenses/ by-nc/4.0/) which permits unrestricted non-commercial use, distribution, and reproduction in any medium, provided the original work is properly cited.

\section{ORCID}

In Joon Hwang

https://orcid.org/0000-0001-5740-3925

Byung Hwa Min

https://orcid.org/0000-0001-8220-3140

Hea Ja Baek

https://orcid.org/0000-0002-4578-5919

Conflict of interests

The authors declare no potential conflict of interest.

\section{Acknowledgements}

This study was supported by a grant from National Institute of Fisheries Science (R2020034).

\section{Authors' contributions}

Conceptualization: Hwang IJ.

Data curation: Min $\mathrm{BH}$.

Investigation: Hwang IJ, Min BH.

Writing - original draft: Hwang IJ, Baek HJ.

Writing - review \& editing: Hwang IJ,

Min BH, Baek HJ.

\begin{abstract}
This study reports the presence of mature and bi-sexual phase gonads in red spotted grouper, Epinephelus akaara after less than a year of cultivation in a commercial indoor tank and a net cage. In December 2018, juveniles were placed in an indoor tank and cultured for five months. In June 2019, the fish were transferred to a net cage and cultured until September. The rearing temperatures ranged from $19.86^{\circ} \mathrm{C}-24.65^{\circ} \mathrm{C}$ in the indoor tank and $21.86^{\circ} \mathrm{C}-27.65^{\circ} \mathrm{C}$ in the net cage. During the net cage culture period, specimens were randomly selected for histological gonad examination. The highest gonadosomatic index (GSI) value was measured in July (3.38 \pm 2.53$)$, and dramatically decreased in August $(0.44 \pm 0.21)$ and September $(0.42 \pm 0.30)$. In July, some mature fish showed signs of vitellogenic stage oocyte development (vitellogenic and oil droplet stage oocytes), but immature fish were in an early developmental stage containing peri-nucleolus stage (PNS) oocytes. Bi-sexual phase gonads containing spermatocytes and spermatids were observed in the lumen and several PNS oocytes. By August and September, most specimens showed early-stage ovary development. However, mature testis (in August) and bi-sexual phase gonads (in September) were also observed. These results provide evidence for early puberty and hermaphroditism in the red spotted grouper.
\end{abstract}

Keywords: Bi-sexual phase gonad, Oocyte, Red spotted grouper, Spermatocyte, Spermatid

\section{INTRODUCTION}

Groupers (Epinephelidae, Pisces: Perciformes) are a tropical and subtropical marine fish comprised of 16 genera and 163 species (Craig et al., 2011), and are commercially valuable in Asian live fish markets (FAO, 2017; Rimmer \& Glamuzina, 2019). The sexual characteristics of Epinephelidae are complex and diverse and classified as gonochorism, protogynous hermaphroditism, and bi-directional sex change (Sadovy de Mitcheson \& Liu, 2008; Liu et al., 2016).

The red spotted grouper, Epinephelus akaara inhabits Korea, southern China, Taiwan, and Japan (Lee et al., 2020). Originally reported as protogynous hermaphrodites (Tseng \& Ho, 1988; Zhang et al., 1988), studies now show they are bidirectional sex changers in laboratory conditions (Okumura, 2001; Chan \& Sadovy, 2002; Liu \& Sadovy, 2004 a,b; Liu et al., 2016), and sexual-pattern plasticity between 
Ethics approval

All experiments were approved by the Institutional Animal Care and Use Committee (IACUC) of National Institute of Fisheries Science (NIFS), Korea. wild and reared fish has been proposed (Liu et al., 2016).

Several studies have been conducted to investigate red spotted grouper reproduction in laboratory conditions for commercial seed production ( $\mathrm{Li}$ et al., 2005, 2006; Lee et al., 2014; Oh et al., 2018; Jeon et al., 2020; Lee et al., 2020), and there is increasing interest from Korean fish farms for commercial cultivation. In this study, we report the occurrence of mature and bi-sexual phase gonads in red spotted groupers reared for less than a year.

\section{MATERIALS AND METHODS}

\section{Fish rearing}

Juvenile red spotted groupers from a commercial hatchery (Muan, Korea; hatched August 2018) were transferred to a commercial fish farm indoor tank (Seosan, Korea) in December 2018. The fish were reared in a 60 ton water tank with a density of $33 \mathrm{fish} / \mathrm{ton}$. The circulation flow rate was 2,500 $\mathrm{L} / \mathrm{h}$, and the water temperature was controlled by a heat pump. The controlled photoperiod was $12 \mathrm{~h}$ light $/ 12 \mathrm{~h}$ dark. The fish were reared in the indoor tank until May 2019, and in June were transferred to a net cage $(6 \mathrm{~m} \times 6 \mathrm{~m} \times 6 \mathrm{~m})$ in the western coastal waters of Korea (Dangamri, Seosan, Korea). Commercial feed ( $\geq 52.0 \%$ crude protein, $\geq 10.0 \%$ crude lipid) was provided twice daily during the culture period.

\section{Specimen measurement and histology}

The total length (TL, cm) and body weight (BW, g) of 30 fish were measured monthly, and from July to September 2019, 10 randomly selected fish were euthanized to calculate the gonadosomatic index (GSI) and hepatosomatic index (HSI). The gonads were fixed in 10\% neutral formalin for 24 $\mathrm{h}$ and paraffin-embedded for histological analyses. The paraffinembedded samples were prepared in 5-6 $\mu \mathrm{m}$ thick sections, stained with Mayer's hematoxylin-eosin, and viewed under a light microscope (BX50, Olympus, Tokyo, Japan).

\section{Statistics}

All of the data are expressed as the mean \pm SEM. The Kruskal-Wallis test and Bonferroni adjustment were performed in SPSS 11.0 for Windows. A p-value of less than 0.05 was considered statistically significant.

\section{RESULTS AND DISCUSSION}

When juveniles were placed in the indoor tank, the mean TL and BW were $5.72 \pm 0.58 \mathrm{~cm}$ and $4.53 \pm 1.34 \mathrm{~g}$, respectively (Table 1; Fig. 1). In May, at the end of the indoor tank culture period, the mean TL increased by $11.72 \pm 1.01 \mathrm{~cm}$, and the mean BW increased by $29.53 \pm 8.22 \mathrm{~g}$. The water

Table 1. Changes in GSI and HSI of cultured red spotted grouper (July to September)

\begin{tabular}{cccc}
\hline \hline & July & August & September \\
\hline GSI & $3.39 \pm 2.54^{\mathrm{a}}$ & $0.44 \pm 0.21^{\mathrm{b}}$ & $0.42 \pm 0.30^{\mathrm{b}}$ \\
$\mathrm{HSI}$ & $2.58 \pm 0.96^{\mathrm{a}}$ & $1.27 \pm 0.27^{\mathrm{b}}$ & $1.31 \pm 0.87^{\mathrm{b}}$ \\
\hline
\end{tabular}

Data were expressed as mean \pm SE $(n=10)$.

${ }^{a, b}$ Different scripts indicate statistically significant differences $(p<0.05)$.

GSI, gonadosomatic index; HSI, hepatosomatic index. 

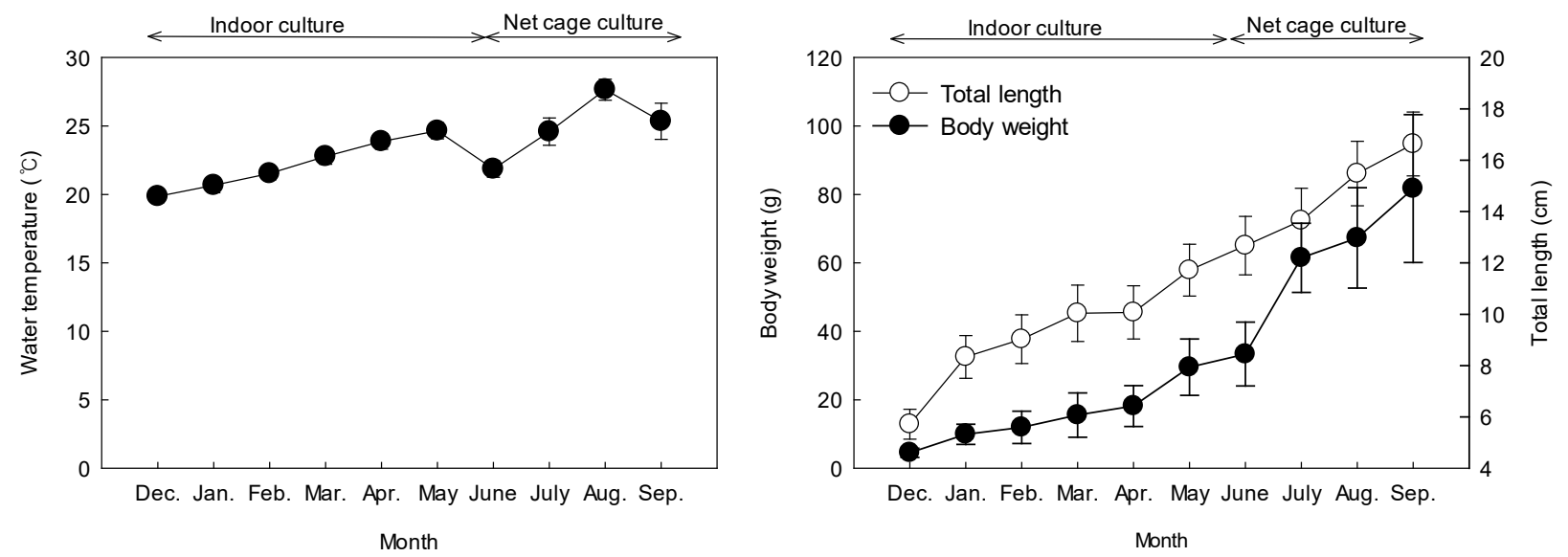

Fig. 1. Changes in water temperature, total length and body weight of red spotted grouper during rearing period. Data were expressed as mean $\pm S E$ $(n=10)$.

temperature during this period ranged from $19.86-24.65 \pm 0.59^{\circ} \mathrm{C}$. In September, at the end of the net cage period, the mean TL increased by $16.63 \pm 1.25 \mathrm{~cm}$, and the mean BW increased by $81.72 \pm 21.60 \mathrm{~g}$. The water temperature during this period ranged from $21.86-27.65 \pm 0.77^{\circ} \mathrm{C}$.

E. akaara juvenile growth is slower than other Korean-cultured grouper species (e.g., Epinephelus bruneus and Hyporthodus septemfasciatus) (Lee \& Hur, 1998; Song et al., 2008). The low growth rates have prompted most red spotted grouper studies to focus on inducing growth, puberty, maturation, and sex inversion via changes in the water temperature, varied photoperiods, and exogenous hormone treatments (Li et al., 2005; Li et al., 2006; Lee et al., 2014; Cho et al., 2015; Lee \& Baek, 2018; Oh et al., 2018; Lee et al., 2020). These studies showed that if red spotted grouper juveniles (110 days after hatching) were reared for eight months in a natural photoperiod and warm water, then the GSI increased as the water temperature increased (Oh et al., 2018). A combination of warm water and longer daylight increased the GSI and spawning in broodstock (Lee et al., 2020).

GSI, HSI were calculated and gonadal histological observations were conducted in July, August, and September (there were few mature fish with swollen abdomens in July) (Fig. 2). The GSI value peaked in July (3.39 \pm 2.54$)$ and rapidly decreased in August $(0.44 \pm 0.21)$; the lowest value $(0.42 \pm 0.30)$ was calculated in September. The HSI value followed the same pattern (July peak: $2.37 \pm 0.96$; August decrease: $1.23 \pm 0.27$, September low: $0.83 \pm 0.87$ ). The GSI values of wild female red spotted

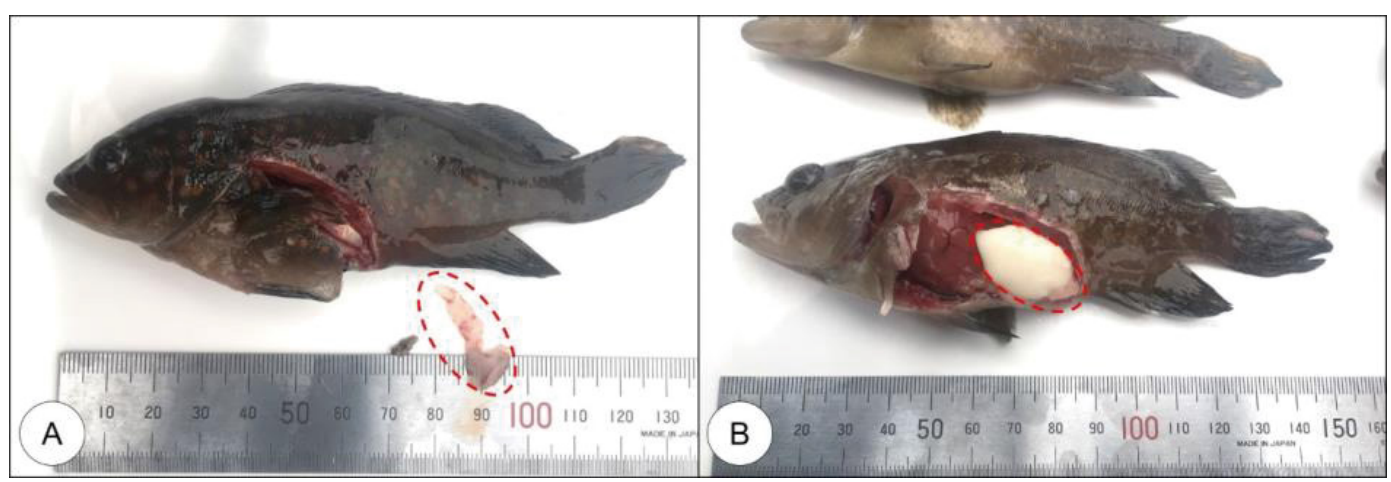

Fig. 2. External morphology of mature red spotted grouper reared less than 1 year (collecting in July, 2019). (A) An immature fish. (B) A mature fish, which has swollen abdomen and mature ovary were observed. Dotted circles indicate gonad. 
groupers ranged from $0.22-1.18$ in immature fish and $0.75-6.66$ in mature fish (Yamamoto \& Kobayashi, 2017), indicating that commercially reared red spotted grouper can reach maturity (based on the GSI value) in less than a year.

In July 2019, most specimens ( $\mathrm{n}=10$ ) were in the early ovarian developmental stage, with perinucleolus stage oocytes (PNS, Fig. 3A, n=5) and oil droplet stage oocytes (Fig. 3B, n=1) in the lumen. We also observed fully vitellogenic oocytes (Fig. 3C, n=2) and bi-sexual phase gonads with scattered spermatocytes (SC) and spermatids (St; Fig. 3D, n=2). In August 2019, all fish ( $\mathrm{n}=10$ ) had immature ovaries with PNS oocytes (Fig. 3E, n=9), except one specimen with a completed testicular gonad, SC, and St (Fig. 3F, n=1). In September, all fish (n=10) had immature ovaries with

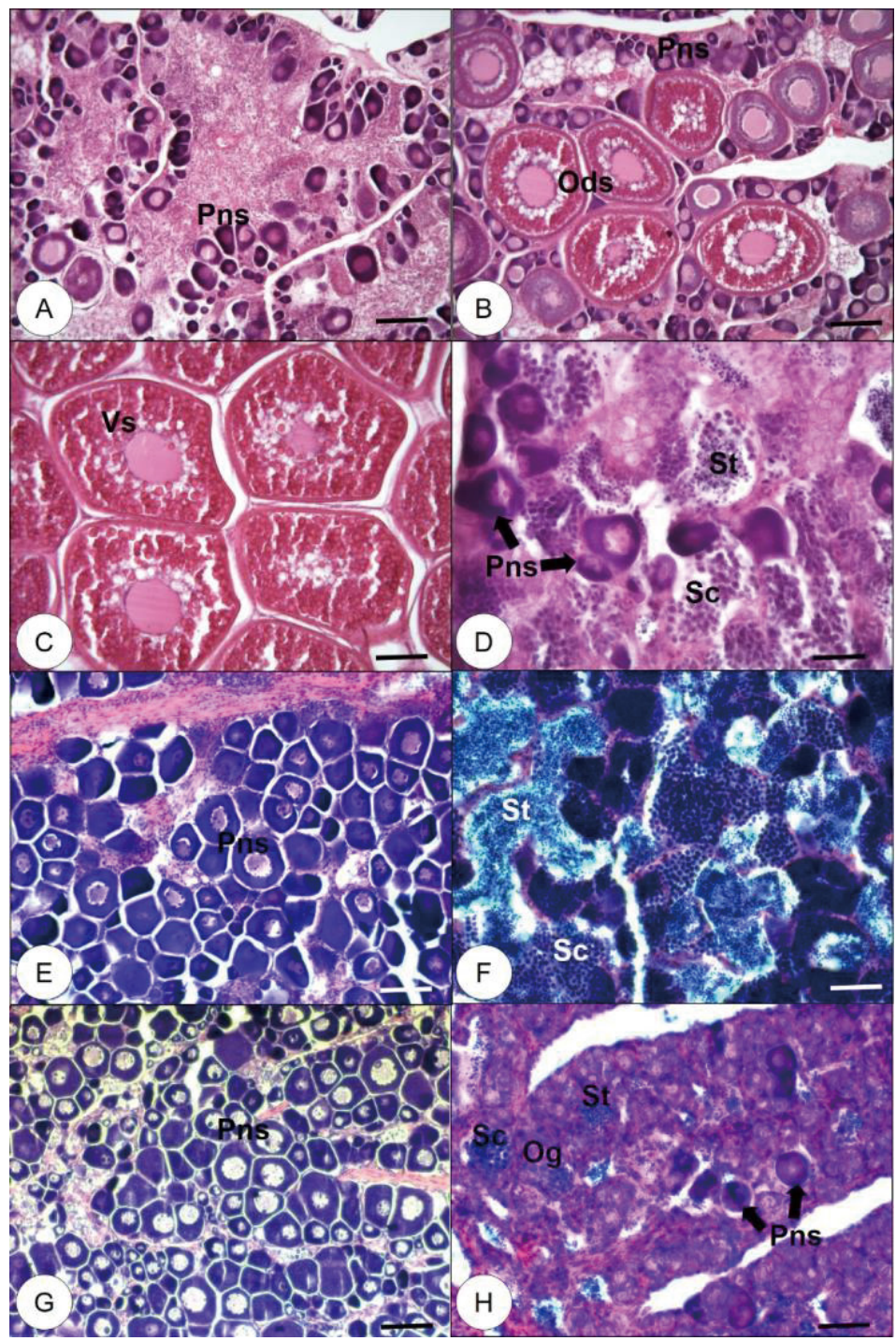

Fig. 3. Histological observation of red spotted grouper gonad collected from July to September, 2019. (A) Immature ovary, which has peri-nucleolus stage (Pns) oocytes (July, 2019). (B) Early vitellogenic ovary, which has several oil droplet stage (Ods) oocytes and Pns oocytes (July, 2019). (C) Mature ovary, which has fully vitellogenic stage (Vs) oocytes (July, 2019). (D) Bisexual phase gonad, which has spermatocytes (Sc), spermatids (St) and scattered Pns (July, 2019). (E) Immature ovary with Pns oocytes (August, 2019). (F) Mature testis, which has Sc and St in the lumen (August, 2019). (G) Immature ovary with Pns oocytes (September, 2019). (H) Bisexual phase gonad, which has oogonia (Og), Sc, St and scattered Pns (September, 2019). Scale bars are $100 \mu \mathrm{m}$ in A, B, C, E, G and $50 \mu \mathrm{m}$ in D, F, H. 
PNS oocytes (Fig. 3G, n=9), except one specimen with abundant oogonia (Og), a few PNS oocytes, and scattered $\mathrm{SC}$ and $\mathrm{St}$ (Fig. $3 \mathrm{H}, \mathrm{n}=1$ ).

Puberty is the process of physical changes by which the immature body prepares for sexual reproduction (Patiño \& Sullivan, 2002; Carillo et al., 2009). This process is closely associated with the endocrine system (brain-pituitary-gonad axis), the environment, and individual factors, such as age and somatic growth (Okuzawa, 2002; Taranger et al., 2010). We could not visually identify the puberty stage because of a low occurrence of mature ovaries and testes (20\% and $10 \%$, respectively), and additional information for puberty stage classification was lacking. The reason for the low occurrence of mature gonads is unclear. Increased water temperature during the culture period (e.g., from $19.86^{\circ} \mathrm{C}$ to $27.65^{\circ} \mathrm{C}$ ) may induce puberty, as reported by $\mathrm{Oh}$ et al. (2018) and Lee et al. (2020). Alternatively, several studies have shown that the red spotted grouper is a bi-directional sex changer, and observations of reverse sex change have been reported (although this species was a protogynous hermaphrodite) (Tanaka et al., 1990; Okumura, 2001; Liu et al., 2016). Liu et al. (2016) reported that the minimum maturation age for both sexes was 41 weeks (about 10 months), and the minimum maturation TL was $14.3 \mathrm{~cm}$ in females and $13.7 \mathrm{~cm}$ in males; our results were similar. We also observed bi-sexual phase gonads in July and September, but with different morphologies. In July, a few specimens were transitioning from female to male, with PNS oocytes, scattered SC and St, and no Og in the gonads. However, in September, a few specimens may have been transitioning from male to female based on the observation of SC and St and proliferation of $\mathrm{Og}$ in the gonads.

Aquaculture requires environmental control, including the artificial induction of maturation and spawning and sufficient broodstock for seed production. Reaching puberty (or maturation) at a younger age may inhibit growth and lead to low productivity in commercial cultures (Carrillo et al., 2009). Future studies should investigate the environmental conditions that inhibit puberty and how these factors affect red spotted grouper growth.

\section{REFERENCES}

Carrillo M, Zanuy S, Felip A, Bayarri MJ, Molés G, Gómez A (2009) Hormonal and environmental control of puberty in perciform fish. Ann N Y Acad Sci 1163:49-59.

Chan TTC, Sadovy Y (2002) Reproductive biology, age and growth in the chocolate hind, Cephalopholis boenak (Bloch, 1790), in Hong Kong. Mar Freshwater Res 53:791-803.

Cho HC, Kim JE, Kim HB, Baek HJ (2015) Effects of water temperature change on the hematological responses and plasma cortisol levels in growing of red spotted grouper, Epinephelus akaara. Dev Reprod 19:19-24.

Craig MT, Sadovy de Mitcheson YJ, Heemstra PC (2011) Groupers of the World: A Field and Market Guide. National Inquiry Services Center [NISC], Grahamstown, South Africa.

Food and Agriculture Organization of the United Nations [FAO] (2017) FishStatJ: A Tool for Fishery Statistics Analysis. Fisheries Division, FAO, Rome, Italia.

Glamuzina B, Skaramuka B, Glavić N, Kožul V (1998) Preliminary studies on reproduction and early life stages in rearing trials with dusky grouper, Epinephelus marginatus (Lowe, 1834). Aquac Res 29:769-771.

Jeon EJ, Kim BH, Lee CH, Lee YD (2020) Response of appetite-related genes in relation to the rearing water temperature in red spotted grouper (Epinephelus akaara). Fish Aquat Sci 23:4.

Lee CK, Hur SB (1998) Effect of live food and water temperature on larval survival of red spotted grouper, Epinephelus akaara.J Aquac 11:565-572. 
Lee CH, Hur SW, Kim BH, Soyano K, Lee YD (2020) Induced maturation and fertilized egg production of the red spotted grouper, Epinephelus akaara, using adaptive physiology of photoperiod and water temperature. Aquac Res 51:2084-2090.

Lee $\mathrm{CH}$, Hur SW, Na OS, Baek HJ, Noh CH, Han SH, Lee YD (2014) Induction of primary male in juvenile red spotted grouper Epinephelus akaara by immersion of $17 \alpha$-methyltestosterone. Dev Reprod 18:127-131.

Lee JW, Baek HJ (2018) Determination of optimal temperature(s) in juvenile red spotted grouper Epinephelus akaara (Temminck \& Schlegel) based on growth performance and stress responses. Aquac Res 49:3228-3233.

Li CJ, Zhou L, Wang Y, Hong YH, Gui JF (2005) Molecular and expression characterization of three gonadotropin subunits common $\alpha, \mathrm{FSH} \beta$ and $\mathrm{LH} \beta$ in groupers. Mol Cell Endocrinol 233:33-46.

Li GL, Liu XC, Lin HR (2006) Effects of aromatizable and nonaromatizable androgens on the sex inversion of redspotted grouper (Epinephelus akaara). Fish Physiol Biochem 32:25-33.

Liu M, Sadovy Y (2004a) The influence of social factors on adult sex change and juvenile sexual differentiation in a diandric, protogynous epinepheline, Cephalopholis boenak (Pisces, Serranidae). J Zool 264:239-248.

Liu M, SadovyY (2004b) Early gonadal development and primary males in the protogynous epinepheline, Cephalopholis boenak.J Fish Biol 65:987-1002.

Liu M, Wang YY, Shan XJ, Kang B, Ding SX (2016) Primary male development two sequentially hermaphroditic groupers, Epinephelus akaara and Epinephelus awoara (Perciformes: Epinephelidae).J Fish Biol 88:1598-1613.

Oh SB, Lee CH, Lee YD (2018) Induction of puberty in red spotted grouper, Epinephelus akaara by water temperature.J Aquac Res Dev 9:1000537.

Okumura S (2001) Evidence of sex reversal towards both directions in reared red spotted grouper Epinephelus akaara. Fish Sci 67:535-537.

Okuzawa K (2002) Puberty in teleosts. Fish Physiol Biochem 26:31-41.

Patiño R, Sullivan CV (2002) Ovarian follicle growth, maturation, and ovulation in teleost fish. Fish Physiol Biochem 26:57-70.

Rimmer MA, Glamuzina B (2019) A review of grouper (Family Serranidae: Subfamily Epinephelinae) aquaculture from a sustainability science perspective. Rev Aquac 11:58-87.

Sadovy de Mitcheson Y, Liu M (2008). Functional hermaphroditism in teleosts. Fish Fisher 9:1-43.

Song YB, Baek HJ, Kim HB, Soyano K, Kim SJ, Lee YD (2008) Induction of maturation and ovulation with HCG treatment in the sevenband grouper Epinephelus septemfasciatus. J Aquac 21:96-101.

Tanaka H, Hirose K, Nogami K, Hattori K, Ishibashi N (1990) Sexual maturation and sex reversal in red spotted grouper, Epinephelus akaara. Bull Natl Res Inst Aquac 17:1-15.

Taranger GL, Carrillo M, Schulz RW, Fontaine P, Zanuy S, Felip A, Weltzien FA, Dufour S, Karlsen Ø, Norberg B, Andersson E, Hansen T (2010) Control of puberty in farmed fish. Gen Comp Endocrinol 165:483-515.

Tseng Wy, Ho SK (1988) The Biology and Culture of Red Grouper. Chien Cheng, Kaohsiung, Taiwan.

Yamamoto M, Kobayashi Y (2017) Spawning period and reliability of sexual distinction based on visual gonad observation of red spotted grouper Epinephelus akaara in the central Seto Inland Sea, Japan. Aquac Sci 65:165-169.

Zhang Q, Hong X, Cai YY, Zhang YS, Zhang J, Dai QN (1988) Cyclic development of gonads in female red grouper, Epinephelus akaara.J Oceanog Taiwan Strait 2:195-212. 